\title{
Effects of neonatal exposure to a glyphosate-based herbicide on female rat reproduction
}

\author{
Paola I Ingaramo, Jorgelina Varayoud, María M Milesi, Marlise Guerrero Schimpf, \\ Mónica Muñoz-de-Toro and Enrique H Luque \\ Instituto de Salud y Ambiente del Litoral (ISAL), Facultad de Bioquímica y Ciencias Biológicas, Universidad \\ Nacional del Litoral - Consejo Nacional de Investigaciones Científicas y Técnicas (CONICET), Santa Fe, Argentina \\ Correspondence should be addressed to E H Luque; Email: eluque@fbcb.unl.edu.ar
}

\begin{abstract}
In this study, we investigated whether neonatal exposure to a glyphosate-based herbicide (GBH) alters the reproductive performance and the molecular mechanisms involved in the decidualization process in adult rats. Newborn female rats received vehicle or $2 \mathrm{mg} / \mathrm{kg} /$ day of a GBH on postnatal days (PND) 1, 3, 5 and 7. On PND90, the rats were mated to evaluate (i) the reproductive performance on gestational day (GD) 19 and (ii) the ovarian steroid levels, uterine morphology, endometrial cell proliferation, apoptosis and cell cycle regulators, and endocrine pathways that regulate uterine decidualization (steroid receptors/COUP-TFII/Bmp2/ Hoxa10) at the implantation sites (IS) on GD9. The GBH-exposed group showed a significant increase in the number of resorption sites on GD19, associated with an altered decidualization response. In fact, on GD9, the GBH-treated rats showed morphological changes at the IS, associated with a decreased expression of estrogen and progesterone receptors, a downregulation of COUP-TFII (Nr2f2) and Bmp2 mRNA and an increased expression of HOXA10 and the proliferation marker Ki67(Mki67) at the IS. We concluded that alterations in endometrial decidualization might be the mechanism of $\mathrm{GBH}$-induced post-implantation embryo loss.

Reproduction (2016) 152 403-415
\end{abstract}

\section{Introduction}

In Argentina, transgenic crops (soybean, maize and cotton) account for three quarters of the total cultivated land (Aparicio et al. 2013). In this country, glyphosate is the most commonly used herbicide, with around 180-200 million liters applied every year (Aparicio et al. 2013). Although regulatory agencies have asserted that glyphosate-based herbicides $(\mathrm{GBH})$ are relatively safe, some reports suggest that they may have harmful effects on health (Dallegrave et al. 2003, Caglar \& Kolankaya 2008, Astiz et al. 2012). In a study performed in a farm population of Ontario, Canada, preconception exposure to glyphosate in women increased the risk of abortions (Arbuckle et al. 2001).

The most adverse effect of GBH on the reproductive tract has been found in male rats, but there are few reports in females. $\mathrm{GBH}$ are aromatase disruptors in different tissues and species (Richard et al. 2005, Benachour et al. 2007, Gasnier et al. 2009, Clair et al. 2012). Male rats treated with a $\mathrm{GBH}$ during the prepubertal period show a decrease in serum testosterone levels together with alterations in the morphology of seminiferous tubules (Romano et al. 2010). Similar reproductive effects have been observed in male offspring rats born to mothers exposed to a $\mathrm{GBH}$ during pregnancy and lactation
(Dallegrave et al. 2003, Romano et al. 2012). Regarding the effects of postnatal exposure to $\mathrm{GBH}$ on reproductive female parameters, female offspring rats born to mothers exposed to different doses of $\mathrm{GBH}$ (50, 150 and $450 \mathrm{mg} / \mathrm{kg}$ ) during pregnancy and lactation show a delay in vaginal opening (Dallegrave et al. 2007).

It is well documented that early postnatal exposure to endocrine-disrupting chemicals might lead to longlasting female reproductive disorders, such as altered cyclicity, decreased conception rates, endometriosis and pregnancy loss (Varayoud et al. 2011, Milesi et al. 2015, Ingaramo et al. 2016). In the last decade, growing data have demonstrated that $\mathrm{GBH}$ may have endocrine-disrupting effects (Gasnier et al. 2009, Clair et al. 2012, Romano et al. 2012, Thongprakaisang et al. 2013). In rodents, once embryos attach to the uterine luminal epithelium, endometrial stromal cells initiate a specialized morphological and functional transformation named decidualization, accompanying the angiogenic and inflammatory responses (Fonseca et al. 2012). Decidualization starts in the vicinity of the implanting embryo, on the antimesometrial (AM) pole of the uterine endometrium, giving rise to the AM decidua and, on the opposite side, cells differentiate to the mesometrial $(M)$ decidua 
(Fonseca et al. 2012). In mice, between gestational day (GD) 5 and GD6, stromal cells situated at the AM decidua cease proliferation and undergo differentiation into decidual cells, forming the primary and secondary decidual zone (Tan et al. 2002). In rats, the AM decidua achieves its maximum development on GD10 (Correia-da-Silva et al. 2004).

The onset of stromal cell proliferation and differentiation is largely controlled by various cell cycle regulatory molecules at different stages of the cell cycle, and an imbalance of the differentiation or proliferation process might promote failures in uterine decidualization (Das 2009, Tan et al. 2002). One of these regulatory molecules is Hoxa10. Hoxa10 is involved in mediating stromal cell proliferation and differentiation through the regulation of hundreds of genes, and a mutation of this gene can lead to implantation and decidualization defects (Lim et al. 1999, Lu et al. 2008). Among the key molecules involved in the signaling pathway that regulates decidualization are progesterone $(\mathrm{P})$ and progesterone receptors (PR), which act by activating a cascade of several factors (Szekeres-Bartho et al. 2009, Zuo et al. 2014). PR regulate COUP-TFII (chicken ovalbumin upstream promoter transcription factor II) through Ptch/Smo (patched gene and smoothened gene) signaling, and then COUP-TFII (NR2F2) regulates bone morphogenetic protein 2 (BMP2), which promotes uterine decidualization (Kurihara et al. 2007). COUPTFII, also known as NR2F2, is a member of the nuclear receptor superfamily and is highly expressed in the uterine stroma during early pregnancy (Kurihara et al. 2007). Bmp2, which belongs to the transforming growth factor $\beta$ (TGF- $\beta$ ) superfamily, regulates proliferation and differentiation and is induced downstream of $\mathrm{P}$ action in the mouse uterine stroma during decidualization (Li et al. 2007). Ablation of the COUP-TFII and Bmp2 genes in the uterine stroma results in decidualization failure, whereas a decrease in the uterine PR and BMP2 expression would be related to increased incidence of fetal resorptions (Kurihara et al. 2007, Wetendorf \& DeMayo 2012, Mestre-Citrinovitz et al. 2015).

In the present work, we hypothesized that early postnatal exposure to a commercial GBH alters reproductive parameters in adult female rats and promotes failure of the endocrine-regulated decidualization process. To test this hypothesis, we investigated the effects of neonatal $\mathrm{GBH}$ exposure on (1) the reproductive performance by determining the pregnancy rate, the number of corpora lutea (CLs), and the number of implantation sites (IS) and resorption sites (RS) on GD19; and (2) the ovarian steroid levels, uterine morphology, endometrial cell proliferation, apoptosis and cell cycle regulators (p27 and cyclin G1), and the endocrine pathways that regulate uterine decidualization (steroid receptors/COUP-TFII/Bmp2/ Hoxa10) at the IS on GD9.

\section{Materials and methods}

\section{Animals}

All the procedures used in this study were approved by the Institutional Ethics Committee of the School of Biochemistry and Biological Sciences (Universidad Nacional del Litoral, Santa Fe, Argentina) and performed in accordance with the principles and procedures outlined in the Guide for the Care and Use of Laboratory Animals issued by the U.S. National Academy of Sciences. Rats of an inbred Wistar-derived strain from the Department of Human Physiology (Universidad Nacional del Litoral, Santa Fe, Argentina) were used. The animals were maintained under a controlled environment $\left(22 \pm 1^{\circ} \mathrm{C}\right.$; lights on from 06:00 to 20:00 h) and had free access to pellet laboratory chow (Nutrición Animal, Santa Fe, Argentina) and tap water. The concentration of phytoestrogens in the diet was not evaluated. However, because food intake of control and GBH-treated rats was equivalent, we assumed that all animals were exposed to the same levels of phytoestrogens (see Kass et al. (2012) for more information regarding food composition). To minimize additional exposures to endocrinedisrupting chemicals, rats were housed in stainless steel cages with wood bedding, and tap water was supplied in glass bottles with rubber stoppers surrounded by a steel ring.

\section{Experimental design}

Adult female rats (90 days old) were housed with males of proven fertility. The day on which sperm was found in the vaginal smear was designated as GD1. Pregnant rats were housed singly and, at delivery, pups were sexed according to the anogenital distance. To minimize the use of siblings and avoid potential litter effects, offspring of the same litter were distributed between different mothers. Cross-fostered litters were adjusted to eight pups, prioritizing a maximum of eight female pups per litter when possible. When fewer than eight females were available, an appropriate number of males were retained. Female pups from each foster mother were assigned to one of the following neonatal treatment groups: (1) control group (C), receiving saline solution $(n=34)$; and (2) $\mathrm{GBH}$ group, receiving a commercial formulation of glyphosate dissolved in saline solution at $2 \mathrm{mg} / \mathrm{kg}(n=38)$. The glyphosate formulation used was a liquid water-soluble formulation containing $66.2 \%$ of glyphosate potassium salt, as its active ingredient, coadjuvants and inert ingredients. Treatments were given on postnatal days (PND) 1, 3, 5 and 7 by sc injections in the nape of the neck. The rodent uterus is not fully developed or differentiated at birth. Uterine development continues during the first postnatal days and due to the high sensitivity to chemical compounds, a brief exposure to endocrine-disrupting chemicals may produce permanent morphological or functional changes (Zama \& Uzumcu 2010, Spencer et al. 2012). The dose of GBH was selected based on the reference dose (RfD) of glyphosate of $2 \mathrm{mg} / \mathrm{kg} /$ day established by the US Environmental Protection Agency (USA EPA 1993), which is an indicative and representative value of levels that are usually not harmful in humans and is in the order of magnitude of the environmental levels detected in our country (Arregui et al. 2004, 
Peruzzo et al. 2008, Aparicio et al. 2013). Although the GBH administered by the subcutaneous route might be metabolized faster if taken orally, this route is the only administration route that warrants the whole incorporation of a chemical compound when an early postnatal exposure model is used. The early postnatal model of exposure to endocrine disruptors has been extensively used in our laboratory in both rodents (Ramos et al. 2007, Monje et al. 2007, 2009, 2010, Varayoud et al. 2008, 2011, Bosquiazzo et al. 2010, Rodriguez et al. 2010, Milesi et al. 2015) and lambs (Rivera et al. 2011) and has been demonstrated as a persuasive paradigm to study short- and long-term consequences of neonatal exposure to hormonally active substances (Rivera et al. 2015). No signs of acute or chronic toxicity were observed, and no significant differences in weight between $\mathrm{GBH}$-exposed and control pups were recorded during the experiment. No alterations in maternal care were detected between the experimental groups. Female pups were weaned on PND21 and held without further treatment until PND90. On PND90, female rats neonatally exposed to $\mathrm{GBH}$ or vehicle were housed for two consecutive weeks with sexually mature untreated males of the same strain and of proven fertility to allow several possible matings. Every morning, vaginal smears were obtained to check for the presence of spermatozoa (Montes \& Luque 1988). The first day on which a sperm-positive smear was detected was considered GD1. Pregnant female rats were assigned to reproductive performance (GD19) or post-implantation (GD9) studies. In summary, only four female pups from any given mother were used in this study, two in each experimental group (control and $\mathrm{GBH}$ ) and one from each group at each time point (GD19 and GD9). The experimental design is shown in Fig. 1.

\section{Evaluation of reproductive performance}

Control ( $n=26$ rats) and GBH-treated female rats ( $n=30$ rats) with a sperm-positive smear were housed separately, and their reproductive performance was evaluated on GD19. The pregnancy rates were calculated as the number of pregnant females/number of females housed with a male $\times 100$. Sperm-positive females were killed on GD19. The ovaries were dissected, and the numbers of profusely irrigated CLs were counted by direct visualization with the aid of a stereomicroscope (Leica). The two-horned uteri were removed and visually inspected to identify RS and IS, following criteria previously described in Varayoud et al. (2011). The RS were defined as endometrial sites with an appended amorphous mass without a fetus and the number of IS as the result of the total number of placentae with fetuses plus the total number of RS. The rate of pre-implantation loss was calculated as follows: (number of CLs - number of IS/number of CLs) $\times 100$, whereas the rate of post-implantation loss was calculated as (number of IS - number of live fetuses)/number of IS $\times 100$ (Perobelli et al. 2012).

\section{Evaluation of uterine histoarchitecture, gene expression and steroid hormone levels on GD9}

\section{Samples}

Control pregnant female rats $(n=8)$ and another group of $\mathrm{GBH}$ exposed pregnant female rats $(\mathrm{GBH}, n=8)$ were killed in the morning of GD9 (post-implantation period), and trunk blood was collected for the hormone assays. For each rat, all IS were collected, weighed and randomly distributed to be processed for different experimental purposes. For immunohistochemistry, the IS were fixed in $10 \%$ buffered formalin for $6 \mathrm{~h}$ at room temperature and embedded in paraffin. For RNA extraction, the dissected IS were immediately frozen in liquid nitrogen and stored at $-80^{\circ} \mathrm{C}$.

\section{Hormone assays}

Serum estradiol $\left(E_{2}\right)$ levels and $P$ were determined by radioimmunoassay after ethyl ether and hexane (Merck) extraction respectively (Varayoud et al. 2011). The antibodies were provided by G. D. Niswender, and labeled hormones were purchased from PerkinElmer Life and Analytical Sciences (Boston, MA, USA). Assay sensitivities were $4 \mathrm{pg} / \mathrm{mL}$ and $1.2 \mathrm{ng} / \mathrm{mL}$ for $E_{2}$ and $P$ respectively. The intra- and inter-assay coefficients of variation were 3.2 and $11 \%$ for $E_{2}$ and 9 and $14.3 \%$ for $\mathrm{P}$ respectively.

\section{Study of the histoarchitecture of the IS}

The IS were morphologically studied using routine histological techniques. At least three histological cross sections paraffinembedded ( $5 \mu \mathrm{m}$ thickness) at different depths of the IS from both the control and $\mathrm{GBH}$ groups were stained with

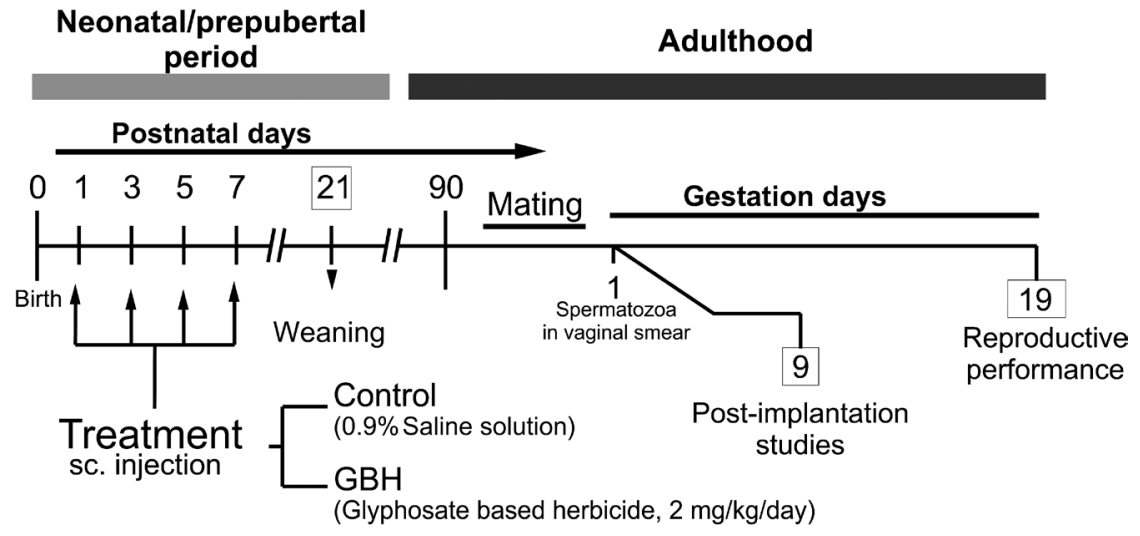

Figure 1 Schematic representation of the experimental protocol used to investigate the effects of neonatal exposure to a glyphosatebased herbicide $(\mathrm{GBH})$ on female fertility and implantation. sc, subcutaneous. 
hematoxylin-eosin ( $\mathrm{H} \& \mathrm{E})$ to provide an overall view of the tissue. Apoptotic features such as shrinkage of the cell, presence of apoptotic bodies and punch images due to rapid phagocytosis by neighboring cells were morphologically evaluated.

\section{Immunohistochemistry and TUNEL assay}

Immunohistochemistry was performed to evaluate protein expression of estrogen receptor- $\alpha(E R \alpha(E S R 1))$, PR (PGR), Ki67 (Mki67), HOXA10, cyclin G1, p27 and desmin. At least three cross sections paraffin-embedded ( $5 \mu \mathrm{m}$ thickness) at different depths at the middle point from each IS were immunostained. Sections were mounted on 3-aminopropyl triethoxysilane (Sigma-Aldrich)-coated slides and microwave pretreatment for antigen retrieval was performed (Varayoud et al. 2011). The endogenous peroxidase activity and non-specific binding sites were blocked. The samples were incubated in a humid chamber first with the specific primary antibody (for 14-16 h at $4^{\circ} \mathrm{C}$ ) and then with the corresponding biotin-conjugated secondary antibody (for $30 \mathrm{~min}$ at room temperature) (Table 1). The reactions were developed using a streptavidin-biotin peroxidase method and diaminobenzidine (Sigma-Aldrich) as a chromogenic substrate. Each immunohistochemical run included positive controls (sections from tissues known to express the proteins of interest) and negative controls (in which the primary antibody was replaced by non-immune serum of the species used to generate the primary antibody) (Ingaramo et al. 2016). For Ki67 immunodetection, the samples were counterstained with Mayer's hematoxylin (Biopur, Rosario, Argentina). Samples were mounted with permanent mounting medium (Eukitt, Sigma-Aldrich).

Apoptotic cells in sections of IS were evaluated by the TUNEL assay using the In Situ Cell Death Detection Kit, POD (Roche), following the manufacturer's instructions. Tissue sections were pretreated with microwave at $350 \mathrm{~W}$ (citrate $0.01 \mathrm{M}, \mathrm{pH}$ 6). Thereafter, sections were rinsed in PBS, immersed in a buffer containing 3\% BSA (SigmaAldrich) and 20\% normal horse serum for $30 \mathrm{~min}$ to block non-specific binding sites. Then, samples were incubated with TUNEL reaction mixture: terminal deoxynucleotidyl transferase (TdT) and fluorescein (FITC)-labeled nucleotide mixture (fluorescein-dUTP) for $60 \mathrm{~min}$ at $37^{\circ} \mathrm{C}$ in a humidified chamber in the darkness. Then, the samples

Table 1 Antibodies used for immunohistochemistry.

\begin{tabular}{|c|c|c|}
\hline Antibodies & Dilution & Supplier \\
\hline \multicolumn{3}{|l|}{ Primary } \\
\hline Anti-PR (clone A0098) & $1 / 500$ & Dako \\
\hline Anti-ER (clone 6F-11) & $1 / 200$ & $\begin{array}{l}\text { Novocastra (Newcastle } \\
\text { upon Tyne, UK) }\end{array}$ \\
\hline Anti-Hoxa10 (sc-17159) & $1 / 50$ & Santa Cruz Biotechnology \\
\hline Anti-Ki67 (clone MIB-5) & $1 / 25$ & Dako \\
\hline Anti-desmin (clone DE-R-11) & $1 / 6400$ & $\begin{array}{l}\text { Novocastra (Newcastle } \\
\text { upon Tyne, UK) }\end{array}$ \\
\hline Anti-cyclin G1 (sc-7865) & $1 / 600$ & Santa Cruz Biotechnology \\
\hline Anti-p27 (sc-528) & $1 / 1200$ & Santa Cruz Biotechnology \\
\hline \multicolumn{3}{|l|}{ Secondary } \\
\hline Anti-mouse & $1 / 100$ & Sigma \\
\hline Anti-rabbit & $1 / 200$ & Sigma \\
\hline Anti-goat & $1 / 200$ & Sigma \\
\hline
\end{tabular}

Reproduction (2016) 152 403-415 were incubated for $30 \mathrm{~min}$ with anti-fluorescein antibody conjugated with POD and the reaction was developed using diaminobenzidine (Sigma-Aldrich) as a chromogenic substrate. Samples were counterstained with Mayer's hematoxylin and then dehydrated and mounted. Cells containing fragmented nuclear chromatin exhibited dark brown staining. For positive control, the involuting rat prostate after the second day of castration was processed in the same way as the experimental samples; a consecutive tissue section processed without TdT was used as a negative control of the TUNEL assay (Ramos et al. 2002).

\section{Quantification of protein expression}

Desmin as a decidualization marker Desmin immunostaining was used as a marker of decidualized endometrium in cross sections of the IS on GD9 (Halperin et al. 1991). The decidualized area (DA) and endometrial area (EA) at the IS on GD9 were measured using the software Image Pro-Plus 5.0.2.9 system (Media Cybernetics, Silver Spring, MD, USA). The images were captured with a Spot Insight version 3.5 color video camera and attached to an Olympus $\mathrm{BH} 2$ microscope using a Dplan $\times 10$ objective (complete structures of the IS were recorded in each section, and three sections per IS were evaluated). The measurement system was spatially calibrated using a Neubauer Chamber. Results are expressed as square millimeters $\left(\mathrm{mm}^{2}\right)$. For each image, a manual selection was performed as described by Brey et al. (2003). In each image, desmin-positive areas corresponding to DA and EA, delimited by myometrium (Myo), were selected. In addition, the DA:EA ratio at the IS on GD9 was calculated.

ER $\alpha, P R, H O X A 10$, cyclin G 1 and $p 27$ proteins The protein expression of ER $\alpha, P R$, Hoxa10, cyclin G1 and p27 was evaluated by image analysis, using the Image Pro-Plus 5.0.2.9 system, as described previously (Ramos et al. 2002). Images of immunostained tissues were recorded with a Spot Insight V3.5 color video camera, attached to a microscope (Olympus) and converted to a gray scale. An automated standard sequence operation was created to measure the integrated optical density (IOD) as a linear combination between the average gray intensity and the relative area occupied by positive cells. Because IOD is a dimensionless parameter, the results are expressed as arbitrary units (Milesi et al. 2015).

The AM and M zones of the IS were assessed. The AM zone was delimited by the myometrium and the adjacent $M$ area. In the $\mathrm{M}$ zone, each compartment was differentially delimited and quantified: luminal and glandular epithelium and subepithelial stroma (a 200- $\mu$ m-wide area adjacent to the epithelium, from the basement membrane toward the outer layers). A representation of the different areas quantified is shown in Fig. 3A. The protein expressions at the AM or $M$ zones were quantified on at least ten fields per section and two sections per rat (separated $50 \mu \mathrm{m}$ from each other).

Ki67 as a proliferation marker Ki67 expression was evaluated in counterstained tissue sections. In the glandular and luminal epithelium of the $M$ zone, a minimum of 2000 nuclei per compartment in each uterine section were counted 
and the results are expressed as the percentage of Ki67positive nuclei. Expression of Ki67 in the subepithelial stroma and AM zone was evaluated by a point counting procedure, as described previously (Ramos et al. 2002). To record the data, a glass disk with a square grid was inserted into a focusing eyepiece of the microscope and the volume fractions $(\mathrm{V} v)$ of the Ki67 (+) cells were calculated by applying the method described by Weibel (1969).

\section{Reverse transcription and real-time quantitative $P C R$ analysis}

RNA extraction and reverse transcription Total RNA was individually extracted from the IS using TRIZOL reagent (Life Technologies) according to the manufacturer's instructions. The concentration and purity of total RNA was determined by measuring the optical density at 260 and $280 \mathrm{~nm}$. All samples were precipitated with ethanol and then dissolved in distilled water, and their quality was verified by gel electrophoresis. Equal quantities $(4 \mu \mathrm{g})$ of total RNA were reverse transcribed into cDNA with Moloney Murine Leukemia Virus reverse

A
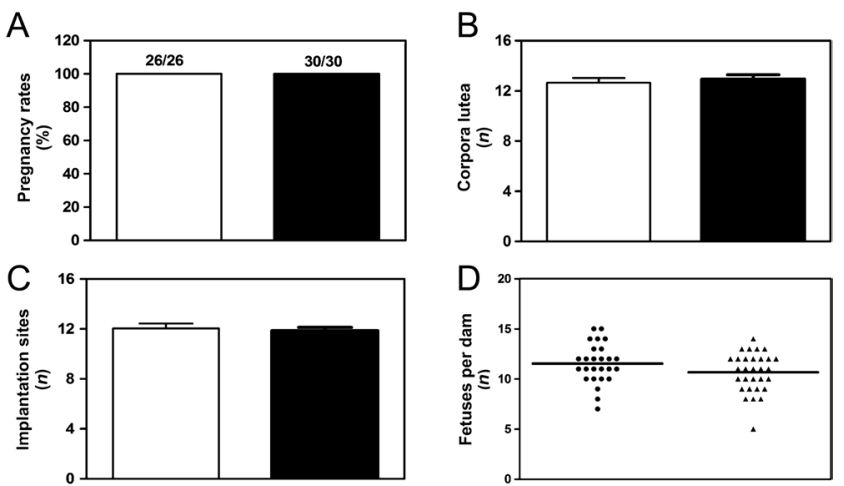

E
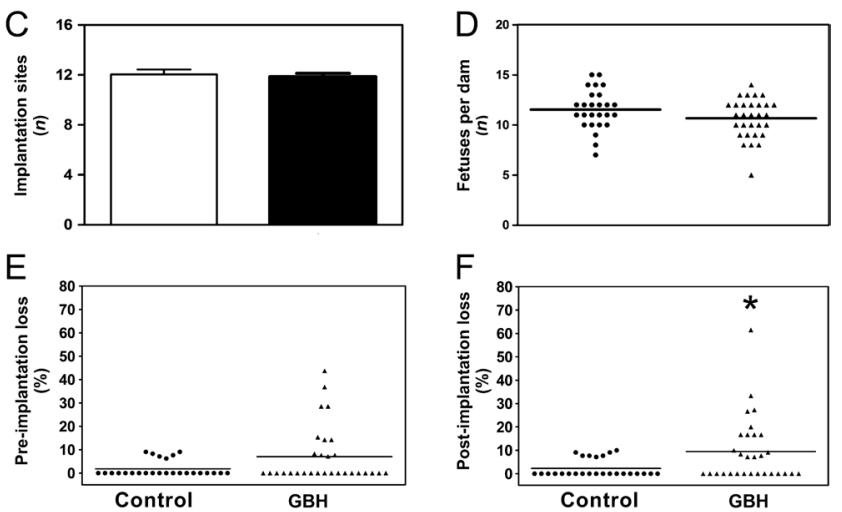

$\mathrm{F}$
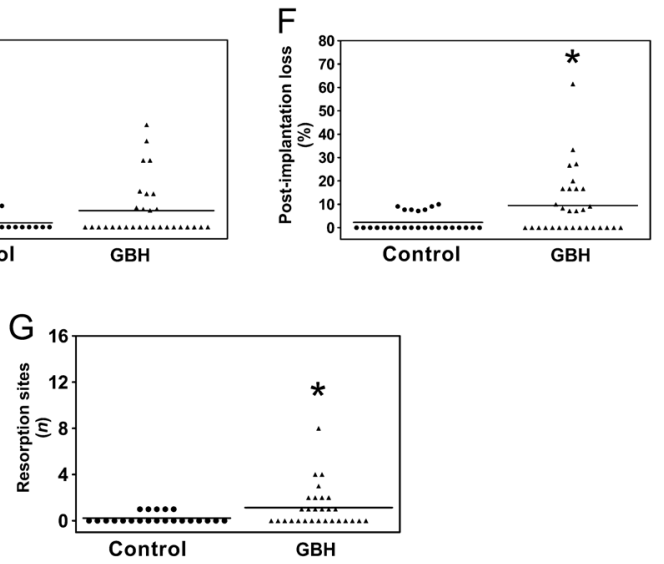

Figure 2 Reproductive performance in female rats neonatally exposed to $\mathrm{GBH}$. (A) Percentage of pregnant females vs the total number of females that were housed with a fertile male. (B) Number of corpora lutea (CLs) and (C) implantation sites (IS) evaluated on GD19 (each column represents the mean \pm S.E.M.). (D) Number of fetuses per dam evaluated on GD19. (E) Percentage of pre-implantation and (F) post-implantation loss (results were calculated as described in 'Materials and methods' section). (G) The numbers of resorption sites on GD19 in each pregnant rat were plotted; the horizontal lines are the mean of each experimental group. ${ }^{*} P<0.05$ vs the control group. transcriptase (300 units; Promega) using 200 pmol of random primers (Promega). Twenty units of ribonuclease inhibitor (RNAout; Invitrogen) and $100 \mathrm{nmol}$ of a deoxynucleotide triphosphate (dNTP) mixture were added to each reaction tube at a final volume of $30 \mu \mathrm{L}$ of $1 \times$ reverse transcriptase buffer. Reverse transcription was performed at $37^{\circ} \mathrm{C}$ for $90 \mathrm{~min}$ and at $42^{\circ} \mathrm{C}$ for $15 \mathrm{~min}$. Reactions were stopped by heating at $80^{\circ} \mathrm{C}$ for $5 \mathrm{~min}$ and cooling on ice.

Real-time quantitative $P C R$ Each reverse-transcribed product was diluted with ribonuclease-free water to a final volume of $60 \mu \mathrm{L}$ and further amplified using the Real-Time Rotor-Gene Q (Qiagen; Tecnolab; Buenos Aires, Argentina). L19 was used as a housekeeping gene. The primer sequences used are described in Table 2. For cDNA amplification, $5 \mu \mathrm{L}$ cDNA were combined with HOT FIREPol EvaGreen qPCR Mix Plus (Solis BioDyne; Biocientífica, Rosario, Argentina) and $10 \mathrm{pmol}$ of each primer (Invitrogen) in a final volume of $20 \mu \mathrm{L}$. After initial denaturation at $95^{\circ} \mathrm{C}$ for $15 \mathrm{~min}$, the reaction mixture was subjected to successive cycles of denaturation at $95^{\circ} \mathrm{C}$ for $15 \mathrm{~s}$, annealing at $52^{\circ} \mathrm{C}$ (Bmp2), $57^{\circ} \mathrm{C}$ (COUP-TFII) or $60^{\circ} \mathrm{C}(\mathrm{ER} \alpha, \mathrm{PR}$ and L19) for 7,4 and $15 \mathrm{~s}$ and extension at $72^{\circ} \mathrm{C}$ for $20 \mathrm{~s}$. Product purity was confirmed by dissociation curves, and random samples were subjected to agarose gel electrophoresis. Controls containing no template DNA were included in all assays, yielding no consistent amplification. Relative gene expression data were calculated using the comparative cycle threshold ( $\left.C_{\mathrm{T}}\right)$ method (Higuchi et al. 1993).
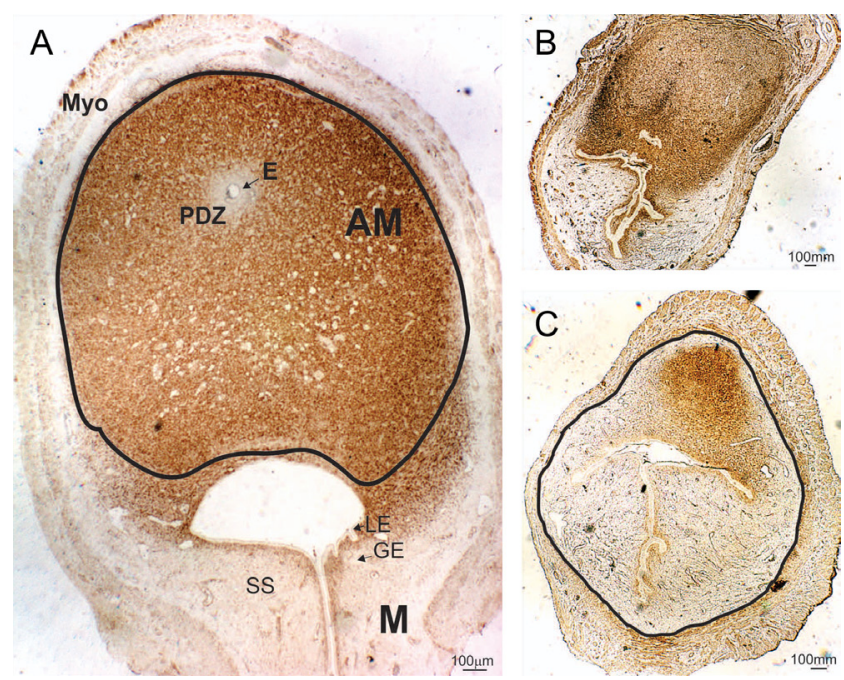

Figure 3 Low-magnification photomicrographs of representative IS of pregnant rats on GD9 immunostained for desmin. (A) Control IS showing different decidualized zones. The antimesometrial (AM) zone is marked with a continuous line. In the AM zone, it is possible to observe the primary decidual zone (PDZ) adjacent to the embryo (E). Surrounding the AM zone, there is a thin layer of smooth muscle (Myo). The mesometrial zone (M) is adjacent to the AM zone. In the mesometrial (M) zone, it is possible to observe the luminal epithelium (LE), the subepithelial stroma (SS) and the glandular epithelium (GE). In the right panel, it is possible to observe two representative IS: (B) from a control and (C) from a GBH-treated rat. The endometrial area is indicated with a continuous line. Note the significant reduction of the desmin-positive area in the GBH-treated group. 
Table 2 Primers and PCR products for gene expression analysis by real-time QPCR.

\begin{tabular}{|c|c|c|c|}
\hline Gene & Primer sequence & Product size $(\mathrm{bp})$ & GenBank accession number \\
\hline Bmp2 & Forward: TCCATCACGAAGAAGCCATC & 95 & NM_017178.1 \\
\hline & Reverse: CTCATCAGTAGGGACAGAACTTAAA & & \\
\hline COUP-TFII & Forward: CCAAGAGCAAGTGGAGAAGC & 116 & NM_080778.2 \\
\hline Progesterone receptor (PR) & $\begin{array}{l}\text { Forward: GACCAGTCTCAACCAACTAGGC } \\
\text { Reverse: ACACCATCAGGCTCATCCAG }\end{array}$ & 137 & NM_022847.1 \\
\hline Estrogen receptor $(E R \alpha)$ & $\begin{array}{l}\text { Forward: ACTACCTGGAGAACGAGCCC } \\
\text { Reverse: CCTTGGCAGACTCCATGATC }\end{array}$ & 153 & NM_012689 \\
\hline Ribosomal protein L19 (L19) & $\begin{array}{l}\text { Forward: AGCCTGTGACTGTCCATTCC } \\
\text { Reverse: TGGCAGTACCCTTCCTCTTC }\end{array}$ & 99 & NM_031103.1 \\
\hline
\end{tabular}

For each sample, $C_{T}$ was calculated as the difference in $C_{T}$ between target mRNA and L19 mRNA. The $C_{T}$ for each sample was calculated using Rotor-Gene Q-Pure Detection software (Version 1.7, Qiagen; Tecnolab). Accordingly, the fold expression over control values was calculated for each target by relative standard curve methods, which are designed to analyze data from real-time PCR (Cikos et al. 2007). For all experimental samples, the relative target quantity was determined from the standard curve, normalized to the relative quantity of the reference gene and finally divided by the normalized target value of the control sample. No significant differences in $C_{T}$ values were observed for the ribosomal protein L19 between the different experimental groups.

\section{Statistical analysis}

Data are expressed as the mean \pm S.E.M. All statistical determinations were performed using GraphPad Prism version 5.03 for Windows (GraphPad Software). The pregnancy rates were analyzed by the Fisher's exact test. The number of RS was analyzed using a generalized linear model with a negative binomial response, using the glm.nb function of the statistical software R (The R Foundation for Statistical Computing). For the other variables, the Mann-Whitney $U$ test was applied. Differences were considered significant at a $P<0.05$.

\section{Results}

\section{Reproductive performance on GD19}

Neonatal exposure to GBH did not affect the pregnancy rates and, on GD19, all rats were pregnant (Fig. 2A). Besides, exposure to GBH did not modify the number of CLs in pregnant females (CLs/rat, 12-14) (Fig. 2B), the number of IS (Fig. 2C) or the number of fetuses per dam (Fig. 2D). However, the GBH group evidenced a higher number of RS among the IS than the control group. The RS were seen as yellow small scars in areas of the IS. It was not possible to establish when the embryo stopped growing, but according to the size of the RS, the event could have taken place after GD9. The percentage of pre-implantation loss (i.e., number of oocytes not fertilized or embryo loss before implantation) in the $\mathrm{GBH}$ group was increased but without reaching statistical significance (Fig. 2E), whereas the percentage of postimplantation loss as well as the number of rats with more than one RS were significantly increased (Fig. 2F and
$\mathrm{G}$ respectively). As the neonatal exposure to $\mathrm{GBH}$ did not affect the number of IS but increased the number of RS, we decided to study uterine morphological changes, ovarian steroid levels and uterine markers of endometrial proliferation and differentiation on GD9. Because during the post-implantation period the uterine proliferation and differentiation processes are regulated through PR action, we focused our assessment in elucidating whether defective uterine decidualization is associated with a failure in key molecules regulated by $\mathrm{P}$.

\section{Ovarian and uterine markers on GD9}

\section{Ovarian steroid levels}

Pregnant rats were evaluated on GD9 to test ovarian steroidogenesis. No differences were observed in the serum levels of $E_{2}$ and $P$ between the experimental groups ( $E_{2}$ levels: control $96.4 \pm 17.1 \mathrm{pg} / \mathrm{mL}$ vs $\mathrm{GBH}$ $69.7 \pm 17.9 \mathrm{pg} / \mathrm{mL}$; P levels: control $40.8 \pm 3.0 \mathrm{ng} / \mathrm{mL}$ vs $\mathrm{GBH} 49.3 \pm 4.5 \mathrm{ng} / \mathrm{mL}$ ).

\section{Morphological and morphometric analysis of the IS and decidual cells}

At first sight, no macroscopic differences were observed between the IS from the control and GBH-exposed groups. On GD9, all IS appeared to be healthy and no signs of abnormality were observed. However, the weights of the IS from the GBH-exposed group were significantly lower than those from controls (Table 3 ). To further investigate the IS at this early developmental stage, the immunohistochemical expression of desmin was used as a marker of decidualized endometrium. A representative IS (two IS were evaluated/rat) from a control rat, showing the DA divided in $\mathrm{AM}$ and $\mathrm{M}$ zones, is shown in Fig. 3A. In the middle of the AM decidua,

Table 3 Measurements at the implantation sites (IS).

\begin{tabular}{lcc}
\hline & \multicolumn{2}{c}{ Experimental groups } \\
\cline { 2 - 3 } Determinations at the IS & Control & GBH-treated \\
\hline Weight $(\mathrm{mg})$ & $63.33 \pm 2.32$ & $53.37 \pm 3.52^{+}$ \\
Decidualized area, DA $\left(\mathrm{mm}^{2}\right)$ & $1.55 \pm 0.32$ & $0.71 \pm 0.18^{+}$ \\
Endometrial area, EA $\left(\mathrm{mm}^{2}\right)$ & $3.01 \pm 0.28$ & $3.12 \pm 0.19$ \\
DA/EA & $0.52 \pm 0.10$ & $0.22 \pm 0.06^{+}$ \\
\hline
\end{tabular}

${ }^{+} P<0.05$ vs control. 
the embryo zone $(\mathrm{E})$ and a primary decidual zone (PDZ) adjacent to the embryo are observed. Surrounding the AM zone, there is a thin layer of smooth muscle (Myo). Adjacent to the AM zone, the M zone exhibits luminal (LE) and glandular epithelium (GE) and subepithelial stroma (SS). The AM zone of both control and GBH-treated rats showed high expression of desmin in the DA (Fig. 3). We found no significant differences in the endometrial area (EA) between GBH-treated and control rats (Table 3). Nevertheless, a significant decrease in the DA and in the DA:EA ratio was found at the IS of the GBH-treated group on GD9 (Table 3). Moreover, a marked decrease in the desmin-positive area was observed at the IS from the GBH group (Fig. 3B). This feature may be a hallmark of $\mathrm{GBH}$ action, which is associated with the reduction of the DA.

\section{Markers associated with endometrial cell decidualization}

$E R \alpha$ Immunohistochemistry was used to assess the protein expression of several markers in each uterine
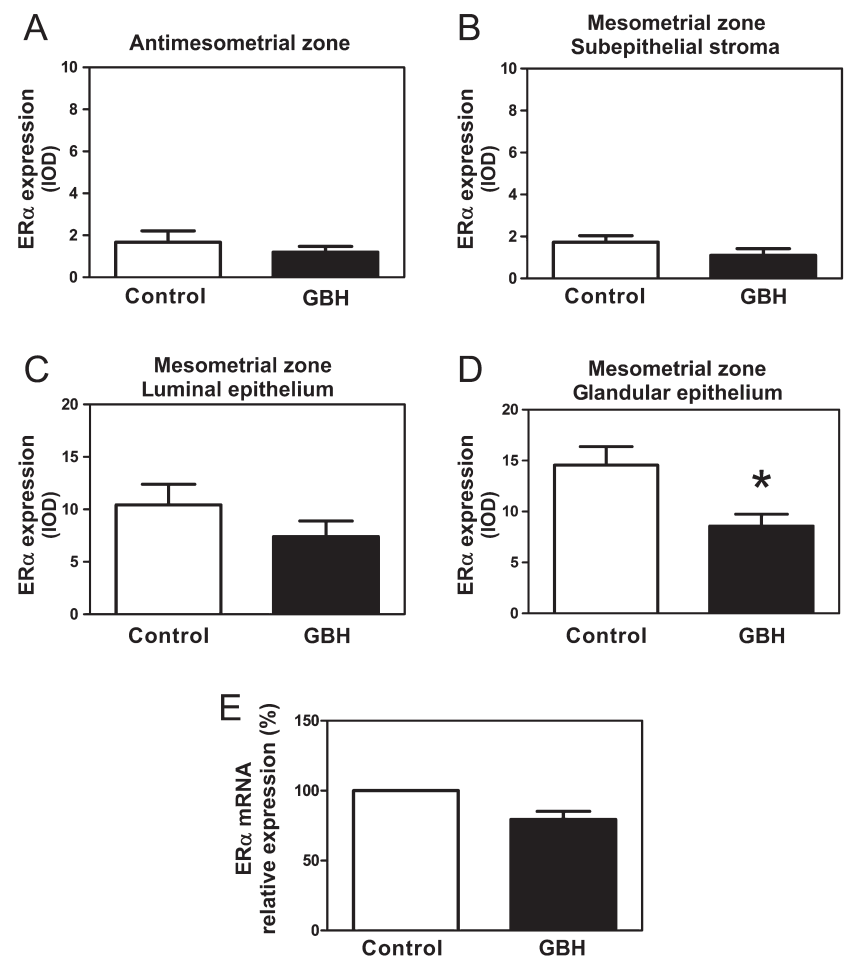

Figure 4 Effects of neonatal GBH exposure on ER $\alpha$ protein and mRNA expression at the IS of pregnant rats on GD9. (A, B, C and D) Quantification of $E R \alpha$ immunostaining in the $M$ and $A M$ zones is expressed as integrated optical density (IOD). Note that ER $\alpha$ expression was lower in the glandular epithelium of the GBH-treated rats. (E) $E R \alpha$ relative mRNA levels of pregnant rats at the IS on GD9 were measured via real-time quantitative RT-PCR. Control values were assigned to a reference level of 100 and values of the GBH group are given as mean \pm S.E.M. The ribosomal protein L19 was used as an internal control. Each column represents the mean \pm S.E.M. $(n=8$ rats per group). ${ }^{*} P<0.05$ vs the control group. compartment of the IS. No differences were observed in the expression level of ER $\alpha$ in the AM zone (Fig. 4A). In the $M$ zone, we found a significant decrease in $E R \alpha$ expression in the glandular epithelium of the GBH group, but no changes in the remaining compartments (Fig. 4B, $\mathrm{C}$ and $\mathrm{D})$. In addition, no differences were observed in the expression of $E R \alpha$ mRNA between experimental groups (Fig. 4E).

PR/COUP-TFII/BMP2 To study whether the $\mathrm{P}$ signaling pathway in the uteri during decidualization was affected by neonatal exposure to $\mathrm{GBH}$, we measured PR protein expression and mRNA at the IS on GD9. PR protein expression was decreased in the $\mathrm{GBH}$-treated group vs the control group, both in the
A
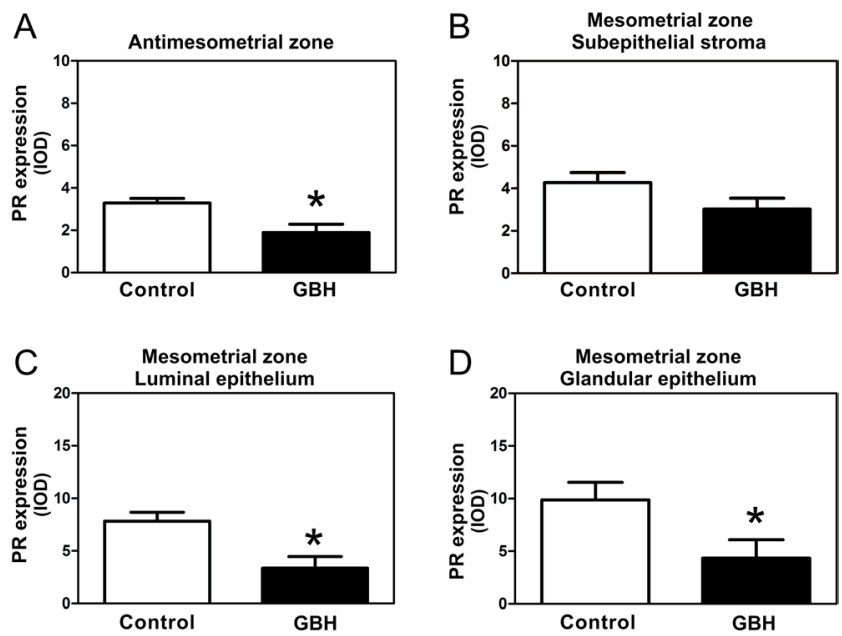

\section{E}
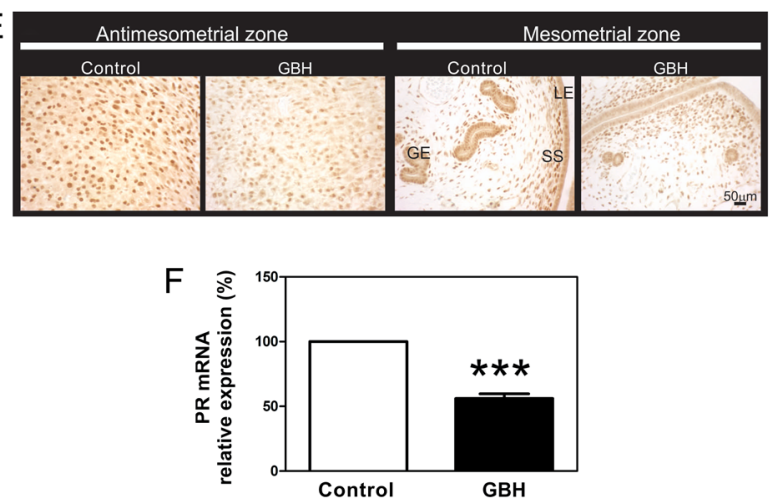

Figure 5 Effects of neonatal GBH exposure on PR protein and mRNA expression at the IS of pregnant rats on GD9. (A, B, C and D) Quantification of PR immunostaining in the $A M$ and $M$ zones is expressed as integrated optical density (IOD). Note that the expression of PR in both zones was affected in GBH-treated rats. (E) Representative photomicrographs of PR expression on sections of the IS. (F) $P R$ relative mRNA levels of pregnant rats at the IS on GD9 were measured via real-time quantitative RT-PCR. Control values were assigned to a reference level of 100 and values of the GBH group are given as mean \pm S.E.M. The ribosomal protein L19 was used as an internal control. Each column represents the mean \pm S.E.M. $(n=8$ per group). ${ }^{*} P<0.05$; ${ }^{* * * P}<0.005$. GE, glandular epithelium; LE, luminal epithelium; SS, subepithelial stroma. Scale bar, $50 \mu \mathrm{m}$. 
$\mathrm{AM}$ and $\mathrm{M}$ zones (in the LE and GE) (Fig. 5A, C and D). No changes in PR protein expression were observed in the subepithelial stroma of the $M$ zone (Fig. 5B). Representative photomicrographs of $\mathrm{PR}$ expression in all uterine compartments are shown (Fig. 5E). $P R$ mRNA levels at the IS on GD9 were measured to further investigate whether the reduction in PR protein expression was extended to mRNA transcription. The mRNA levels of $P R$ at the IS of rats neonatally exposed to $\mathrm{GBH}$ was significantly lower (Fig. 5F).

Subsequently, the PR/COUP-TFII/Bmp2 signaling pathway was evaluated in depth to better understand the increased number of RS found in the GBH-treated group. Therefore, we performed additional measurements of mRNA expression of key molecules participating in the PR pathway. Interestingly, we found that the GBH group showed lower mRNA levels of COUP-TFII and Bmp2 at the IS on GD9 (Fig. 6A and B).

Hoxa10 No changes were observed in the expression of Hoxa10 in the AM zone between both experimental groups (Fig. 7A); however, the expression of Hoxa10 was significantly increased in the subepithelial stroma of the $\mathrm{M}$ zone (Fig. 7B). Hoxa10 immunohistochemical expression was negative in the epithelium. Representative photomicrographs of Hoxa10 protein expression in all uterine compartments are shown in Fig. 7C.

\section{Endometrial cell proliferation, apoptosis and cell cycle regulators}

To better understand the increase in the number of RS and the decrease in the DA following GBH treatment, we assessed the expression of the proliferation marker Ki67 at the IS on GD9. A remarkable increase in Ki67 expression levels in all compartments was observed (Fig. 8A, B and C). Ki67 was negative in the glandular epithelium of both experimental groups.

In the AM zone, the expression of cyclin G1 and p27 was significantly decreased (Fig. 8D, E, F and G), whereas in the $M$ zone, we found a significant decrease in cyclin G1 in the SS and in p27 in the LE of the GBH group (Fig. 8F, G and H). A low percentage of apoptotic
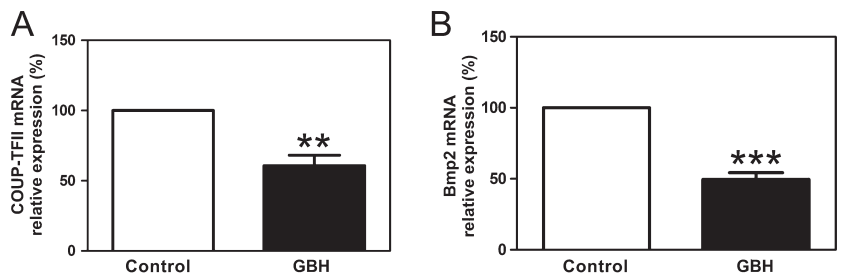

Figure 6 Effects of neonatal GBH exposure on the mRNA levels of COUP-TFII and Bmp2 at the IS of pregnant rats on GD9, quantified by real-time RT-PCR. Control values were assigned to a reference level of 100 and values of the GBH group are given as mean \pm S.E.M. The ribosomal protein L19 was used as an internal control. Each column represents the mean \pm S.E.M. ( $n=8$ per group). ${ }^{* *} P<0.01$ and ${ }^{* * *} P<0.005$ vs the control group.
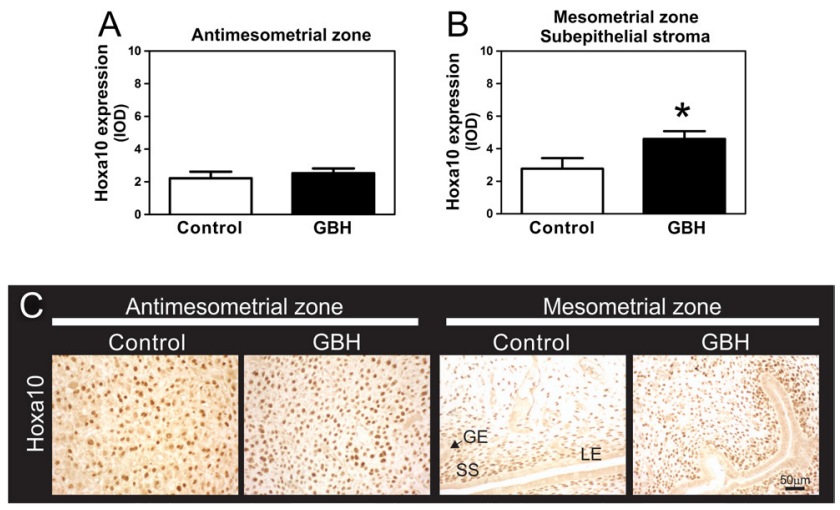

Figure 7 Effects of neonatal GBH exposure on Hoxa10 protein expression at the IS of pregnant rats on GD9. (A and B)

Quantification of Hoxa10 immunostaining in the $A M$ and $M$ zones is expressed as the IOD. Hoxa10 immunostaining is increased in the subepithelial stroma of GBH-exposed rats. (C) Representative photomicrographs of Hoxa10 expression on sections of the IS. Each column represents the mean \pm S.E.M. $\left(n=8\right.$ per group). ${ }^{*} P<0.05$ vs the control group. GE, glandular epithelium; LE, luminal epithelium; SS, subepithelial stroma. Scale bar, $50 \mu \mathrm{m}$.

cells was detected by the TUNEL in situ assay of IS and no differences between experimental groups were found (Fig. 8K). Representative photomicrographs of Ki67, cyclin G1 and p27 protein expression and the TUNEL in situ assay are shown in Fig. 8J and K.

\section{Discussion}

In this work, we assessed the effects of the neonatal treatment of $\mathrm{GBH}$ on the aspects of the female rat reproduction. Reproductive parameters were analyzed on GD19 by counting the number of resorptions vs that of live fetuses in the uterine horn. The number of RS in the group neonatally treated with GBH was significantly increased, thus suggesting an adverse effect of the herbicide on embryo development. On the other hand, exposure to GBH did not affect the ovulation rate (evaluated by the number of CLs) or the ovarian steroidogenesis in accordance with the serum levels of $E_{2}$ and $P$. As the herbicide did not affect the number of IS, we suggest that miscarriage occurs after implantation and that the adverse effects of GBH may be directed to the uterus.

Few studies have tested the effects of GBH on the female reproductive tract. Thus, the present results using an animal model are interesting because they allow suggesting a link between the reproductive failures observed in women living in rural zones and the massive use of herbicides (Arbuckle et al. 2001, Greenlee et al. 2003, Kumar 2011). Despite the well-established safety of glyphosate for humans by regulatory agencies (US EPA 1993, WHO 1994), the International Agency for Research on Cancer (IARC 2015), based on studies that are available in the scientific literature, has recently classified this herbicide 

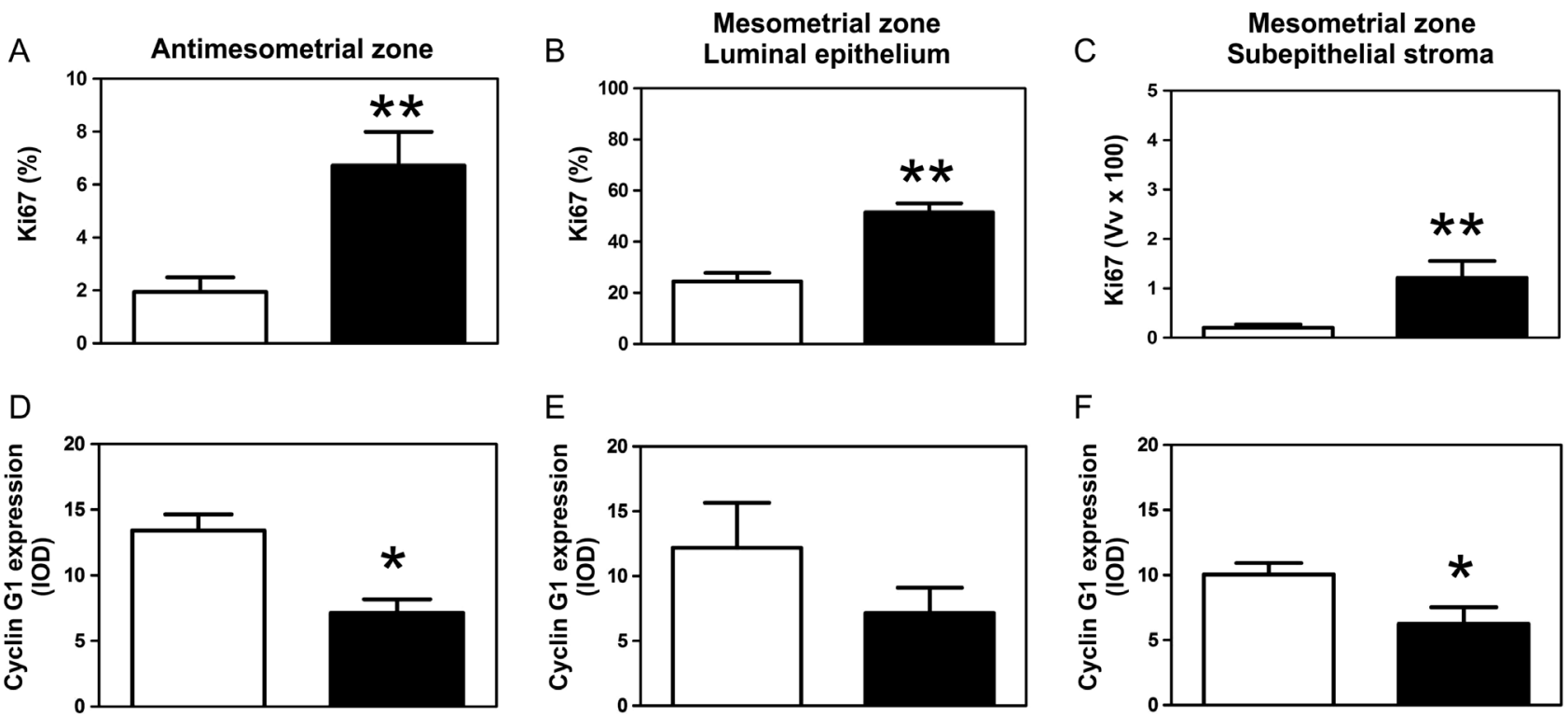

E
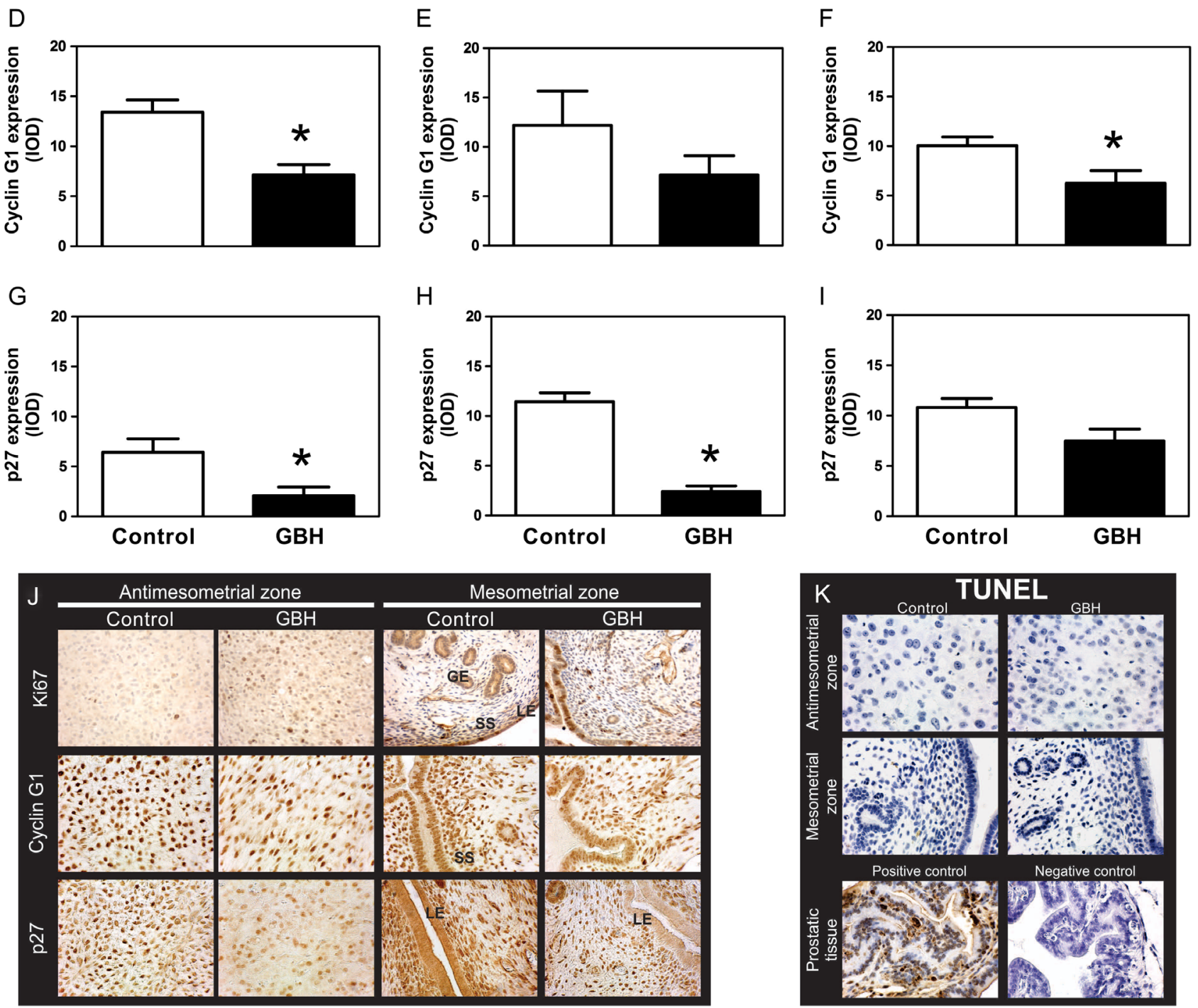

Figure 8 Effects of neonatal GBH exposure on Ki67, cyclin G1 and p27 protein expression at the IS of pregnant rats on GD9. (A, B and C) Quantification of Ki67, (D, E and F) cyclin G1 and (G, H and I) p27 immunostaining in the AM and M zones is expressed as the IOD. Ki67 showed that there is an increased proliferation in both zones of the IS in GBH-treated rats. Cyclin G1 and p27 showed decreased expression in the AM zone of $\mathrm{GBH}$-treated rats as well as decreased expression in the SS and LE of the M zone respectively. (J) Representative

photomicrographs of Ki67, cyclin G1 and p27 expression on sections of the IS. Each column represents the mean \pm S.E.M. ( $n=8$ per group). ${ }^{*} P<0.05$ and ${ }^{* *} P<0.01$ vs the control group. (K) Representative photomicrographs of the TUNEL assay. No apoptotic cell was observed in the IS of pregnant rats on GD9 of either the GBH or control groups. Apoptosis of prostatic cells with cytoplasmic and nuclear condensation and nuclear fragmentation are observed in the positive control, while no staining was detected in a consecutive tissue section when TdT was avoided (negative control of TUNEL assay). GE, glandular epithelium; LE, luminal epithelium; SS, subepithelial stroma. Scale bar, $50 \mu \mathrm{m}$. 
as probably carcinogenic to humans (Group 2A). It has also been suggested that chronic, low-level exposure may lead to developmental and reproductive health problems, particularly for men and women residing in agricultural areas associated with heavy herbicide use (Williams et al. 2012). In a study performed in an Ontario Farm Population, women provided information on spontaneous abortions and it was demonstrated that preconception exposure to glyphosate increased the risk of abortions (Arbuckle et al. 2001).

In several species, it has been recognized that the synchrony between the needs of developing embryos and the secretions of the uterus are critical for implantation and to maintain a successful pregnancy (Pope 1988, Bourdiec \& Akoum 2014). Following embryo implantation, one of the critical steps to establish pregnancy in rodents and humans is the optimal decidualization of endometrial stromal cells (ESCs) (Kusama et al. 2014). This step is intricately regulated by $E_{2}$ and $P$, which activate the transcription of target genes through the binding of their cognate receptors (Wetendorf \& DeMayo 2012). Here, we detected no alterations in ovarian steroid hormone levels on GD9 or in the number of CLs on GD19 in GBH-exposed animals. Therefore, our results suggest that the uterus rather than the ovary is the principal organ involved in the reproductive failure in $\mathrm{GBH}$-exposed rats.

In this work, we described morphological differences between the experimental groups at the IS on GD9. Effects similar to those described here have been observed by other authors when uterine PR and Bmp2 signaling was altered (Lee et al. 2007, Mestre-Citrinovitz et al. 2015). A decrease in the decidual zone at the IS of $\mathrm{GBH}$-treated rats on GD6 and GD7 has been reported in rats treated with onapristone (PR antagonist) (MestreCitrinovitz et al. 2015). Moreover, Lee et al. (2007) demonstrated that, after a decidualization stimulus, mice with conditional ablation of Bmp2 failed to increase horn size.

An adequate paracrine signaling is required for proper differentiation of the embryo surrounding the stroma within the uterus. Paracrine signaling is essential in the support and development of the implanted embryo in decidualization (Wetendorf \& DeMayo 2012). As PR signaling is critical for a successful pregnancy (Wetendorf \& DeMayo 2012), the decreased $\mathrm{PR}$ expression in most of the uterine compartments of the GBH group on GD9 suggests that the failure in maintaining the pregnancy might be explained by defects in the uterine PR signaling pathway.

Knockout mice have been pivotal in demonstrating that members of the Bmp family are critical within early pregnancy (Wetendorf \& DeMayo 2012). In mice with conditional ablation of Bmp2 in uterine cells but which normally express uterine PR, embryo attachment is normal, but the uterine stroma is unable to undergo the decidual reaction to support further embryonic development (Lee et al. 2007). The intraluminal injection of recombinant Bmp2 in one horn of the uterus in the ablated mouse can partially rescue the decidual response, suggesting that the observed phenotype is due to the developmental ablation of Bmp2 (Lee et al. 2007). In this study, Bmp2 mRNA was clearly decreased at the IS of the GBH group on GD9. Thus, in GBHtreated rats, $\mathrm{P}$ signaling failed due to the altered PR/ Bmp2 pathway.

COUP-TFII makes a link between PR and Bmp2. Bmp2 expression in COUP-TFII mutants is greatly reduced (Kurihara et al. 2007). This molecule is regulated through $\mathrm{PR}$ in the decidual tissue and deficiency of COUP-TFII produces failures in the decidualization process and early embryonic lethality due to cardiovascular defects (Takamoto et al. 2005, Kurihara et al. 2007). During the peri-implantation period, COUP-TFII regulates embryo attachment and decidualization through controlling $E R \alpha$ activity. In the post-implantation period, COUP-TFII expression is still required to facilitate placentation (Lee et al. 2010). The decidualization process is under the control of $P$ and $E_{2}$ in the presence of blastocysts or deciduogenic stimuli. Pawar et al. (2015) showed that if ER $\alpha$ is conditionally deleted from both the epithelial and stromal compartments of the uterus, using PR-Cre, the resulting $E R \alpha^{\mathrm{d} / \mathrm{d}}$ mice display complete loss of decidual response. In the present work, in the post-implantation period (GD9), we detected a decrease in ER $\alpha$ protein levels in the uterine glands from the $\mathrm{GBH}$ group and no changes in the rest of the uterine compartments. Although some authors have suggested that estrogenic influence via $E R \alpha$ is minimal for the induction of decidualization in pregnant mice on GD8 (Paria et al. 1999, Tan et al. 1999), others have shown a strong positive ER $\alpha$ expression in the uterine glands and a more intense expression for $\mathrm{ER} \alpha \mathrm{mRNA}$ at the $\mathrm{M}$ pole (Tan et al. 1999). Additionally, in mice in which ER $\alpha$ is ablated in uterine luminal and glandular epithelia but retained in the stroma, the decidualization defect could be due to the lack of secretion of an ER $\alpha$ regulated paracrine factor from the glands (Pawar et al. 2015). Although we did not demonstrate a specific role of $E R \alpha$ in decidualization on GD9, we might suggest that the abnormal glandular ER $\alpha$ expression on GD9 in the GBH group could contribute to the failure in decidualization. Moreover, studies have indicated that uterine ER $\alpha$-PR signaling is vulnerable to exposure to environmental endocrine-disrupting chemicals with either estrogenic or antiestrogenic activity ( $\mathrm{Li}$ et al. 2016). Accordingly, the defective decidualization observed in the $\mathrm{GBH}$ group may be explained by a dysregulation of ER $\alpha$-PR signaling.

Besides the changes described in the PR pathway, we evaluated the proliferation of decidual tissue. In the uterus, Hoxa10 is regulated in response to $E_{2}$ and $P$ and promotes proliferation of human ESCs through 
the regulation of hundreds of genes (Lu et al. 2008). For stromal cell differentiation, the different regulatory mechanisms of the cell cycle should be appropriately balanced; PR and Hoxa10 are key molecules that participate in proliferation and differentiation during decidualization (Das 2009). Increased Hoxa10 expression in the stroma and $M$ region and increased proliferation (by Ki67 expression) in the uteri of the $\mathrm{GBH}$ group allow us to assume that the cell cycle is dysregulated. During stromal cell decidualization, HOXA10 is downregulated and ESCs exit the cell cycle and enter differentiation (Qian et al. 2005). Accordingly, cyclin G1 and p27 downregulation may impair the exit of ESCs from the cell cycle, allowing these cells to remain proliferating. Hoxa10 is a key player in the regulation of cyclin Gs in the uterus. Expression of cyclin G1, a negative regulator of the cellular cycle, is also controlled by $\mathrm{P}$ via its nuclear receptor. Cyclin G1 is primarily associated with stromal cell proliferation and differentiation during decidualization (Yue et al. 2005). On the other hand, the expression of p27 in the peri-implantation uterus has been closely associated with the onset of decidualization (Tan et al. 2002). Thus, the increased expression of Hoxa10, together with a dysregulated expression of PR and a decrease in cyclin G1 and p27 activity in the GBH groups, could be the molecular mechanism to explain the proliferation/differentiation balance. It has been described that $\mathrm{P}$ appears to regulate apoptosis of stromal cells by modulating Bax and Bcl2 expression (Dai et al. 2000, Joswig et al. 2003). Although the $P$ pathway was altered in $\mathrm{GBH}$ exposed rats, we found no differences in apoptosis between control and treated rats on GD9. Therefore, the increase in the number of RS found in the GBH group could be explained by defective uterine signaling of PR/COUP-TFII/Bmp2, ER and Hoxa10, which lead to an imbalance between differentiation/proliferation and consequently, defective decidualization.

In summary, we found a significant increase in the number of RS on GD19 associated with an altered decidualization response, probably due to a defective differentiation/proliferation uterine process. In fact, on GD9, the GBH-treated rats showed an increased expression of the proliferation marker $\mathrm{Ki} 67$ and Hoxa10, an increased expression of cyclin G1 and p27, a decreased expression of estrogen and progesterone receptors - key regulators of decidualization - and a downregulation of COUP-TFII and Bmp2 mRNA at the IS.

Pregnancy loss may occur for many reasons, not all of which can be identified. Some of these causes include genetic, uterine or hormonal abnormalities; reproductive tract infections; and tissue rejection. Based on the present results, we suggest that exposure to low levels of GBH may also be associated with pregnancy loss in humans and animals.

\section{Declaration of interest}

The authors declare that there is no conflict of interest that could be perceived as prejudicing the impartiality of the research reported.

\section{Funding}

This work was supported by Universidad Nacional del Litoral (Santa Fe, Argentina) (CAI+D program), Argentine Council for Scientific and Technological Research (CONICET), and the Argentine Agency for the Promotion of Science and Technology (ANPCYT).

\section{Acknowledgements}

P I I, M M M, JV and E H L are career investigators and M G M is a fellow of the CONICET.

\section{References}

Aparicio VC, De Geronimo E, Marino D, Primost J, Carriquiriborde P \& Costa JL 2013 Environmental fate of glyphosate and aminomethylphosphonic acid in surface waters and soil of agricultural basins. Chemosphere931866-1873.(doi:10.1016/j.chemosphere.2013.06.041)

Arbuckle TE, Lin Z \& Mery LS 2001 An exploratory analysis of the effect of pesticide exposure on the risk of spontaneous abortion in an Ontario farm population. Environmental Health Perspectives 109 851-857. (doi:10.1289/ehp.01109851)

Arregui MC, Lenardon A, Sanchez D, Maitre MI, Scotta R \& Enrique S 2004 Monitoring glyphosate residues in transgenic glyphosate-resistant soybean. Pest Management Science 60 163-166. (doi:10.1002/ (ISSN)1526-4998)

Astiz M, de Alaniz MJ \& Marra CA 2012 The oxidative damage and inflammation caused by pesticides are reverted by lipoic acid in rat brain. Neurochemistry International 61 1231-1241. (doi:10.1016/j. neuint.2012.09.003)

Benachour N, Sipahutar H, Moslemi S, Gasnier C, Travert C \& Seralini GE 2007 Time- and dose-dependent effects of roundup on human embryonic and placental cells. Archives of Environmental Contamination and Toxicology 53 126-133. (doi:10.1007/s00244-006-0154-8)

Bosquiazzo VL, Varayoud J, Muñoz-de-Toro M, Luque EH \& Ramos JG 2010 Effects of neonatal exposure to bisphenol A on steroid regulation of vascular endothelial growth factor expression and endothelial cell proliferation in the adult rat uterus. Biology of Reproduction 82 86-95. (doi:10.1095/biolreprod.109.078543)

Bourdiec A \& Akoum A 2014 [Embryo implantation: role of interleukin 1 family members]. Médecine Sciences 30 644-650. (doi:10.1051/ medsci/20143006014)

Brey EM, Lalani Z, Johnston C, Wong M, McIntire LV, Duke PJ \& Patrick CW Jr 2003 Automated selection of DAB-labeled tissue for immunohistochemical quantification. Journal of Histochemistry and Cytochemistry 51 575-584. (doi:10.1177/002215540305100503)

Caglar S \& Kolankaya D 2008 The effect of sub-acute and sub-chronic exposure of rats to the glyphosate-based herbicide Roundup. Environmental Toxicology and Pharmacology 25 57-62. (doi:10.1016/j. etap.2007.08.011)

Cikos S, Bukovska A \& Koppel J 2007 Relative quantification of mRNA: comparison of methods currently used for real-time PCR data analysis. BMC Molecular Biology 8 113. (doi:10.1186/1471-2199-8-113)

Clair E, Mesnage R, Travert C \& Seralini GE 2012 A glyphosate-based herbicide induces necrosis and apoptosis in mature rat testicular cells in vitro, and testosterone decrease at lower levels. Toxicology in Vitro 26 269-279. (doi:10.1016/j.tiv.2011.12.009)

Correia-da-Silva G, Bell SC, Pringle JH \& Teixeira NA 2004 Patterns of uterine cellular proliferation and apoptosis in the implantation site 
of the rat during pregnancy. Placenta 25 538-547. (doi:10.1016/j. placenta.2003.11.007)

Dai D, Moulton BC \& Ogle TF 2000 Regression of the decidualized mesometrium and decidual cell apoptosis are associated with a shift in expression of Bcl2 family members. Biology of Reproduction 63 188-195. (doi:10.1095/biolreprod63.1.188)

Dallegrave E, Mantese FD, Coelho RS, Pereira JD, Dalsenter PR \& Langeloh A 2003 The teratogenic potential of the herbicide glyphosateRoundup in Wistar rats. Toxicology Letters 142 45-52. (doi:10.1016/ S0378-4274(02)00483-6)

Dallegrave E, Mantese FD, Oliveira RT, Andrade AJ, Dalsenter PR \& Langeloh A 2007 Pre- and postnatal toxicity of the commercial glyphosate formulation in Wistar rats. Archives of Toxicology $\mathbf{8 1}$ 665-673. (doi:10.1007/s00204-006-0170-5)

Das SK 2009 Cell cycle regulatory control for uterine stromal cell decidualization in implantation. Reproduction 137 889-899. (doi:10.1530/REP-08-0539)

Fonseca BM, Correia-da-Silva G \& Teixeira NA 2012 The rat as an animal model for fetoplacental development: a reappraisal of the postimplantation period. Reproductive Biology 12 97-118. (doi:10.1016/ S1642-431X(12)60080-1)

Gasnier C, Dumont C, Benachour N, Clair E, Chagnon MC \& Seralini GE 2009 Glyphosate-based herbicides are toxic and endocrine disruptors in human cell lines. Toxicology 262 184-191. (doi:10.1016/j. tox.2009.06.006)

Greenlee AR, Arbuckle TE \& Chyou PH 2003 Risk factors for female infertility in an agricultural region. Epidemiology $\mathbf{1 4}$ 429-436. (doi:10.1097/01.ede.0000071407.15670.aa)

Halperin R, Fleminger G, Kraicer PF \& Hadas E 1991 Desmin as an immunochemical marker of human decidual cells and its expression in menstrual fluid. Human Reproduction 6 186-189.

Higuchi R, Fockler C, Dollinger G \& Watson R 1993 Kinetic PCR analysis: real-time monitoring of DNA amplification reactions. Biotechnology $\mathbf{1 1}$ 1026-1030. (doi:10.1038/nbt0993-1026)

IARC Working Group 2015 Glyphosate. In Some Organophosphate Insecticides and Herbicides: Diazinon, Glyphosate, Malathion, Parathion, and Tetrachlorvinphos, vol 112. IARC Monographs. Prog, 1-92.

Ingaramo PI, Milesi MM, Schimpf MG, Ramos JG, Vigezzi L, Muñoz-de-Toro M, Luque EH \& Varayoud J 2016 Endosulfan affects uterine development and functional differentiation by disrupting Wnt7a and beta-catenin expression in rats. Molecular and Cellular Endocrinology 425 37-47. (doi:10.1016/j.mce.2016.02.011)

Joswig A, Gabriel HD, Kibschull M \& Winterhager E 2003 Apoptosis in uterine epithelium and decidua in response to implantation: evidence for two different pathways. Reproductive Biology and Endocrinology 1 44. (doi:10.1186/1477-7827-1-44)

Kass L, Altamirano GA, Bosquiazzo VL, Luque EH \& Muñoz-de-Toro M 2012 Perinatal exposure to xenoestrogens impairs mammary gland differentiation and modifies milk composition in Wistar rats. Reproductive Toxicology 33 390-400. (doi:10.1016/j.reprotox.2012.02.002)

Kumar S 2011 Occupational, environmental and lifestyle factors associated with spontaneous abortion. Reproductive Sciences 18 915-930. (doi:10.1177/1933719111413298)

Kurihara I, Lee DK, Petit FG, Jeong J, Lee K, Lydon JP, DeMayo FJ, Tsai MJ \& Tsai SY 2007 COUP-TFIl mediate progesterone regulation of uterine implantation by controlling ER activity. PLoS Genetics 3 e102. (doi:10.1371/journal.pgen.0030102)

Kusama K, Yoshie M, Tamura K, Daikoku T, Takarada T \& Tachikawa E 2014 Possible roles of the CAMP-mediators EPAC and RAP1 in decidualization of rat uterus. Reproduction 147 897-906. (doi:10.1530/REP-13-0654)

Lee DK, Kurihara I, Jeong JW, Lydon JP, DeMayo FJ, Tsai MJ \& Tsai SY 2010 Suppression of ERalpha activity by COUP-TFII is essential for successful implantation and decidualization. Molecular Endocrinology 24 930-940. (doi:10.1210/me.2009-0531)

Lee KY, Jeong JW, Wang J, Ma L, Martin JF, Tsai SY, Lydon JP \& DeMayo FJ 2007 Bmp2 is critical for the murine uterine decidual response. Molecular and Cellular Biology 27 5468-5478. (doi:10.1128/MCB.00342-07)

Li Q, Davila J, Kannan A, Flaws JA, Bagchi MK \& Bagchi IC 2016 Chronic exposure to bisphenol A affects uterine function during early pregnancy in mice. Endocrinology 157 1764-1774. (doi:10.1210/en.2015-2031)

Li Q, Kannan A, Wang W, Demayo FJ, Taylor RN, Bagchi MK \& Bagchi IC 2007 Bone morphogenetic protein 2 functions via a conserved signaling pathway involving Wnt4 to regulate uterine decidualization in the mouse and the human. Journal of Biological Chemistry 282 31725-31732. (doi:10.1074/jbc.M704723200)

Lim H, Ma L, Ma WG, Maas RL \& Dey SK 1999 Hoxa-10 regulates uterine stromal cell responsiveness to progesterone during implantation and decidualization in the mouse. Molecular Endocrinology 13 1005-1017. (doi:10.1210/mend.13.6.0284)

Lu Z, Hardt J \& Kim JJ 2008 Global analysis of genes regulated by HOXA10 in decidualization reveals a role in cell proliferation. Molecular Human Reproduction 14 357-366. (doi:10.1093/molehr/gan023)

Mestre-Citrinovitz AC, Kleff V, Vallejo G, Winterhager E \& Saragueta P 2015 A suppressive antagonism evidences progesterone and estrogen receptor pathway interaction with concomitant regulation of Hand2, Bmp2 and ERK during early decidualization. PLOS ONE 10 e0124756. (doi:10.1371/journal.pone.0124756)

Milesi MM, Alarcon R, Ramos JG, Muñoz-de-Toro M, Luque EH \& Varayoud J 2015 Neonatal exposure to low doses of endosulfan induces implantation failure and disrupts uterine functional differentiation at the pre-implantation period in rats. Molecular and Cellular Endocrinology 401 248-259. (doi:10.1016/j.mce.2014.11.028)

Monje L, Varayoud J, Luque EH \& Ramos JG 2007 Neonatal exposure to bisphenol A modifies the abundance of estrogen receptor alpha transcripts with alternative $5^{\prime}$-untranslated regions in the female rat preoptic area. Journal of Endocrinology 194 201-212. (doi:10.1677/JOE-07-0014)

Monje L, Varayoud J, Muñoz-de-Toro M, Luque EH \& Ramos JG 2009 Neonatal exposure to bisphenol A alters estrogen-dependent mechanisms governing sexual behavior in the adult female rat. Reproductive Toxicology 28 435-442. (doi:10.1016/j.reprotox.2009.06.012)

Monje L, Varayoud J, Muñoz-de-Toro M, Luque EH \& Ramos JG 2010 Exposure of neonatal female rats to bisphenol A disrupts hypothalamic LHRH pre-mRNA processing and estrogen receptor alpha expression in nuclei controlling estrous cyclicity. Reproductive Toxicology $\mathbf{3 0}$ 625-634. (doi:10.1016/j.reprotox.2010.08.004)

Montes GS \& Luque EH 1988 Effects of ovarian steroids on vaginal smears in the rat. Acta Anatomica 133 192-199. (doi:10.1159/000146639)

Paria BC, Tan J, Lubahn DB, Dey SK \& Das SK 1999 Uterine decidual response occurs in estrogen receptor-alpha-deficient mice. Endocrinology 140 2704-2710. (doi:10.1210/en.140.6.2704)

Pawar S, Laws MJ, Bagchi IC \& Bagchi MK 2015 Uterine epithelial estrogen receptor-alpha controls decidualization via a paracrine mechanism. Molecular Endocrinology 29 1362-1374. (doi:10.1210/me.2015-1142)

Perobelli JE, Alves TR, de Toledo FC, Fernandez CD, Anselmo-Franci JA, Klinefelter GR \& Kempinas Wde G 2012 Impairment on sperm quality and fertility of adult rats after antiandrogen exposure during prepuberty. Reproductive Toxicology 33 308-315. (doi:10.1016/j. reprotox.2011.12.011)

Peruzzo PJ, Porta AA \& Ronco AE 2008 Levels of glyphosate in surface waters, sediments and soils associated with direct sowing soybean cultivation in north pampasic region of Argentina. Environmental Pollution 156 61-66. (doi:10.1016/j.envpol.2008.01.015)

Pope WF 1988 Uterine asynchrony: a cause of embryonic loss. Biology of Reproduction 39 999-1003. (doi:10.1095/biolreprod39.5.999)

Qian K, Chen H, Wei Y, Hu J \& Zhu G 2005 Differentiation of endometrial stromal cells in vitro: down-regulation of suppression of the cell cycle inhibitor p57 by HOXA10? Molecular Human Reproduction 11 245-251. (doi:10.1093/molehr/gah147)

Ramos JG, Varayoud J, Bosquiazzo VL, Luque EH \& Muñoz-de-Toro M 2002 Cellular turnover in the rat uterine cervix and its relationship to estrogen and progesterone receptor dynamics. Biology of Reproduction 67 735-742. (doi:10.1095/biolreprod.101.002402)

Ramos JG, Varayoud J, Monje L, Moreno-Piovano G, Muñoz-de-Toro M \& Luque EH 2007 Diethylstilbestrol alters the population dynamic of neural precursor cells in the neonatal male rat dentate gyrus. Brain Research Bulletin 71 619-627. (doi:10.1016/j.brainresbull.2006.12.004)

Richard S, Moslemi S, Sipahutar H, Benachour N \& Seralini GE 2005 Differential effects of glyphosate and roundup on human placental cells and aromatase. Environmental Health Perspectives 113 716-720. (doi:10.1289/ehp.7728)

Rivera OE, Varayoud J, Rodriguez HA, Muñoz-de-Toro M \& Luque EH 2011 Neonatal exposure to bisphenol A or diethylstilbestrol alters the ovarian follicular dynamics in the lamb. Reproductive Toxicology 32 304-312. (doi:10.1016/j.reprotox.2011.06.118) 
Rivera OE, Varayoud J, Rodriguez HA, Santamaria CG, Bosquiazzo VL, Osti M, Belmonte NM, Muñoz-de-Toro M \& Luque EH 2015 Neonatal exposure to xenoestrogens impairs the ovarian response to gonadotropin treatment in lambs. Reproduction 149 645-655. (doi:10.1530/REP-140567)

Rodriguez HA, Santambrosio N, Santamaria CG, Muñoz-de-Toro M \& Luque EH 2010 Neonatal exposure to bisphenol A reduces the pool of primordial follicles in the rat ovary. Reproductive Toxicology 30 550-557. (doi:10.1016/j.reprotox.2010.07.008)

Romano MA, Romano RM, Santos LD, Wisniewski P, Campos DA, de Souza PB, Viau P, Bernardi MM, Nunes MT \& de Oliveira CA 2012 Glyphosate impairs male offspring reproductive development by disrupting gonadotropin expression. Archives of Toxicology 86 663-673. (doi:10.1007/s00204-011-0788-9)

Romano RM, Romano MA, Bernardi MM, Furtado PV \& Oliveira CA 2010 Prepubertal exposure to commercial formulation of the herbicide glyphosate alters testosterone levels and testicular morphology. Archives of Toxicology 84 309-317. (doi:10.1007/s00204-009-0494-z)

Spencer TE, Dunlap KA \& Filant J 2012 Comparative developmental biology of the uterus: insights into mechanisms and developmental disruption. Molecular and Cellular Endocrinology 354 34-53. (doi:10.1016/j. mce.2011.09.035)

Szekeres-Bartho J, Halasz M \& Palkovics T 2009 Progesterone in pregnancy; receptor-ligand interaction and signaling pathways. Journal of Reproductive Immunology 83 60-64. (doi:10.1016/j.jri.2009.06.262)

Takamoto N, Kurihara I, Lee K, Demayo FJ, Tsai MJ \& Tsai SY 2005 Haploinsufficiency of chicken ovalbumin upstream promoter transcription factor II in female reproduction. Molecular Endocrinology 19 2299-2308. (doi:10.1210/me.2005-0019)

Tan J, Paria BC, Dey SK \& Das SK 1999 Differential uterine expression of estrogen and progesterone receptors correlates with uterine preparation for implantation and decidualization in the mouse. Endocrinology $\mathbf{1 4 0}$ 5310-5321. (doi:10.1210/en.140.11.5310)

Tan J, Raja S, Davis MK, Tawfik O, Dey SK \& Das SK 2002 Evidence for coordinated interaction of cyclin D3 with p21 and cdk6 in directing the development of uterine stromal cell decidualization and polyploidy during implantation. Mechanisms of Development 111 99-113. (doi:10.1016/S0925-4773(01)00614-1)

Thongprakaisang S, Thiantanawat A, Rangkadilok N, Suriyo T \& Satayavivad J 2013 Glyphosate induces human breast cancer cells growth via estrogen receptors. Food and Chemical Toxicology 59 129-136. (doi:10.1016/j.fct.2013.05.057)

US EPA 1993 EPA Reregistration eligibility document, Glyphosate, Office of Prevention, Pesticides and Toxic Substances Washington, DC.
Varayoud J, Ramos JG, Bosquiazzo VL, Lower M, Muñoz-de-Toro M \& Luque EH 2011 Neonatal exposure to bisphenol A alters rat uterine implantation-associated gene expression and reduces the number of implantation sites. Endocrinology 152 1101-1111. (doi:10.1210/ en.2009-1037)

Varayoud J, Ramos JG, Bosquiazzo VL, Muñoz-de-Toro M \& Luque EH 2008 Developmental exposure to bisphenol A impairs the uterine response to ovarian steroids in the adult. Endocrinology 149 5848-5860. (doi:10.1210/en.2008-0651)

Weibel ER 1969 Stereological principles for morphometry in electron microscopic cytology. International Review of Cytology 26 235-302. (doi:10.1016/S0074-7696(08)61637-X)

Wetendorf M \& DeMayo FJ 2012 The progesterone receptor regulates implantation, decidualization, and glandular development via a complex paracrine signaling network. Molecular and Cellular Endocrinology 357 108-118. (doi:10.1016/j.mce.2011.10.028)

WHO 1994 Glyphosate. In Environmental Health Criteria, 3rd edn. Geneva, Switzerland: WHO.

Williams AL, Watson RE \& DeSesso JM 2012 Developmental and reproductive outcomes in humans and animals after glyphosate exposure: a critical analysis. Journal of Toxicology and Environmental Health. Part B, Critical Reviews 15 39-96. (doi:10.1080/10937404.20 12.632361)

Yue L, Daikoku T, Hou X, Li M, Wang H, Nojima H, Dey SK \& Das SK 2005 Cyclin G1 and cyclin G2 are expressed in the periimplantation mouse uterus in a cell-specific and progesterone-dependent manner: evidence for aberrant regulation with Hoxa-10 deficiency. Endocrinology 146 2424-2433. (doi:10.1210/en.2004-1605)

Zama AM \& Uzumcu M 2010 Epigenetic effects of endocrine-disrupting chemicals on female reproduction: an ovarian perspective. Frontiers in Neuroendocrinology 31 420-439. (doi:10.1016/j.yfrne.2010.06.003)

Zuo RJ, Zhao YC, Lei W, Wang TS, Wang BC \& Yang ZM 2014 Crystallin alphaB acts as a molecular guard in mouse decidualization: regulation and function during early pregnancy. FEBS Letters 588 2944-2951. (doi:10.1016/j.febslet.2014.05.045)

Received 29 March 2016

First decision 26 April 2016

Revised manuscript received 5 July 2016

Accepted 1 August 2016 